Bangladesh Rice J. 19(1):41 - 48, 2015

\title{
Evaluation of Water Productivity for Different Rice Based Cropping Sequences in Gazipur
}

\author{
S Parveen ${ }^{*}$, M S A Khan ${ }^{2}$, M N Hassan ${ }^{1}$ and M A Sattar ${ }^{1}$
}

\begin{abstract}
Declining trend of water resources for Boro rice cultivation in different areas lead researchers and farmers to find out alternate cropping sequences. A field experiment was conducted in silty clay soil to evaluate the water productivity and profitability of different rice based cropping sequences during 2006-07 to 2008-09 at the BRRI farm, Gazipur. Three cropping sequences viz T. Aman-Boro-Fallow, T. Aman-Wheat-Mungbean and T. Aman-Potato-Mungbean and three water regimes assigned differently for each component crops were evaluated in a split-plot design. Among the cropping sequences, T. Aman-Potato-Mungbean with one irrigation at vegetative and two in reproductive stages for T. Aman rice, three irrigation each at 20,40 and 60 DAS for potato and two irrigations for mungbean gave significantly higher rice equivalent yield of 33.40, 22.59 and $28.44 \mathrm{t} \mathrm{ha}^{-1}$ in 2006-07, 2007-08 and 2008-09 respectively. The variation in yield equivalence was mostly governed by potato crop grown in Rabi season. The maximum water productivity of $23.41,18.57$ and $23.62 \mathrm{~kg} \mathrm{ha}^{-1} \mathrm{~mm}$ was recorded in rainfed for T. Aman and mungbean and one irrigation for potato in 2006-07, 2007-08 and 2008-09 respectively. The higher yield of potato raised the water productivity in T. Aman-PotatoMungbean cropping sequence. Maximum net return of Tk 2,28,056, 2,75,389 and 4,05,986 and maximum BCR values from T. Aman-Potato- Mungbean cropping sequence with $\mathrm{T}_{3}$ irrigation regimes of the respective crops during 2006-7, 2007-8 and 2008-9 respectively indicated that the sequence would be suitable for getting higher yield and economic return.
\end{abstract}

Key words: Cropping sequence, rice equivalent yield, water productivity

INTRODUCTION

Water is a major component for rice production. To produce one $\mathrm{kg}$ rice, 3000 litre of water is needed (Bhuiyan et al., 1995). At present, about $80 \%$ of groundwater is used for irrigation, of which $73 \%$ is used exclusively by Boro farmers (Rahman and Ahmed, 2008). Availability of fresh water has been declining day by day. Approximately $50 \%$ of fresh water is used for rice cultivation (Guerra et al., 1998). The average area coverage's for Aus (pre-monsoon), T. Aman (wet season) and Boro (dry season) rice are 0.9, 5.05 and 4.6 Mha, with corresponding production of 2.29, 14.69 and 27.0 MMT respectively (BBS, 2009). Among the three seasons, Boro mainly depends on irrigation that needs nearly one-third of the total production cost. The major cropping patterns of agriculture in Bangladesh mostly consist of rice based cereal crops (Haque, 1998). More than $60 \%$ of the total cropped areas are covered by Boro-Fallow-T. Aman rice cropping sequence (FRG 1997). About 2.4 Mha crop land is occupied by this cropping sequence in Bangladesh (Ladha et al., 2003; Dawe et al., 2004; Bhuiyan et al., 2004). It is alarming that, lowering

1Irrigation and Water Management Division, BRRI and 2Agronomy Division, BARI, Gazipur 1701. *Corresponding author's E-mail: sahana.iwm@brri.gov.bd of groundwater has been occurred in some intensive cropped area in north-west region of Bangladesh due to climate change situation. Due to shortage of irrigation water farmers are likely to change their cropping pattern by shifting Boro rice with non-rice crops. However, a lot of information is available on rice based crop sequences/cropping systems for different soil and agro-climatic conditions of the country. Scant information is available on the relative effect of different irrigation levels for individual crops under a particular crop sequence. Total water requirement as well as water productivity for a particular cropping pattern is also lacking. Therefore, the present experiment was planned to find out suitable cropping sequence and the amount of water required for the component crops, and to determine the productivity and profitability of the system.

\section{MATERIALS AND METHODS}

Field experiments were conducted at BRRI farm, Gazipur during 2006-07 to 2008-09. The treatment 
comprised three levels of irrigation and three rice based crop sequences, laid out in split plot design with crop sequences in main plot and irrigation in sub plot, replicated three times. Different rice based crop sequences/cropping system were: $\mathrm{P}_{1}=$ T. Aman-Boro-Fallow, $\mathrm{P}_{2}=\mathrm{T}$. Aman-WheatMungbean, and $\mathrm{P}_{3}=\mathrm{T}$. Aman-Potato-Mungbean. Table 1 shows the irrigation treatments of different crops and the fertilizer managements that were followed. Table 2 shows the variety of different crops, seeding time and harvesting times.

Rainfall data measured by Tru-check rain gauges were used to estimate effective rainfall by using the water use- rainfall ratio method (Dastane, 1974). In this method, rainfall total for a certain group of days during the growing season was computed. The number of days in a group was based broadly on the soil type. For the study area, a 5-day grouping was used as the soil type is silty clay and falls under 5 -day grouping.

Table 1. Irrigation treatments and fertilizer managements used in different rice based cropping systems.

\begin{tabular}{|c|c|c|}
\hline Crop & Irrigation & Fertilizer \\
\hline T. Aman & $\begin{array}{l}\mathrm{T}_{1}=\text { Rainfed } \\
\mathrm{T}_{2}=\text { One irrigation at vegetative and one in reproductive } \\
\text { stage } \\
\mathrm{T}_{3}=\text { One irrigation at vegetative and two in reproductive } \\
\text { stage }\end{array}$ & $\begin{array}{l}150+100+70+33+50 \mathrm{~kg} \mathrm{ha}^{-1} \\
\text { urea, TSP, MP, gypsum and } \\
\text { zinc sulphate }\end{array}$ \\
\hline Boro & $\begin{array}{l}\mathrm{T}_{1}=\text { Continuous standing water } \\
\mathrm{T}_{2}=\text { Saturation level } \\
\mathrm{T}_{3}=\text { Irrigation after three days of disappearing standing } \\
\text { water }\end{array}$ & $\begin{array}{l}220+120+85+28+50 \mathrm{~kg} \mathrm{ha}-1 \\
\text { urea, TSP, MP, gypsum and } \\
\text { zinc sulphate }\end{array}$ \\
\hline Wheat & $\begin{array}{l}\mathrm{T}_{1}=\text { One irrigation }(17-21 \mathrm{DAS}) \\
\mathrm{T}_{2}=\text { Two irrigations }(17-21 \mathrm{DAS}+55-60 \mathrm{DAS}) \\
\mathrm{T}_{3}=\text { Three irrigations }(17-21 \mathrm{DAS}+55-60 \mathrm{DAS}+70-75 \\
\text { DAS })\end{array}$ & $\begin{array}{l}220+180+50+120 \mathrm{~kg} \mathrm{ha}^{-1} \\
\text { urea, TSP, MP, gypsum }\end{array}$ \\
\hline Potato & $\begin{array}{l}\mathrm{T}_{1}=\text { One irrigation }(20-25 \mathrm{DAS}) \\
\mathrm{T}_{2}=\text { Two irrigations }(20-25 \mathrm{DAS}+40-45 \mathrm{DAS}) \\
\mathrm{T}_{3}=\text { Three irrigations }(20-25 \mathrm{DAS}+40-45 \mathrm{DAS}+60-65 \\
\text { DAS) }\end{array}$ & $\begin{array}{c}250+150+250+120+8+10 \mathrm{~kg} \\
\text { ha-1 urea, TSP, MP, gypsum, } \\
\text { zinc sulphate and boron }\end{array}$ \\
\hline Mungbean & $\begin{array}{l}\mathrm{T}_{1}=\text { Rainfed } \\
\mathrm{T}_{2}=\text { One irrigation } \\
\mathrm{T}_{3}=\text { Two irrigations }\end{array}$ & $\begin{array}{l}50+85+35 \mathrm{~kg} \mathrm{ha}^{-1} \text { urea, TSP, } \\
\mathrm{MP}\end{array}$ \\
\hline
\end{tabular}

Table 2. Variety, seeding time and harvesting time of different crops used in different rice based cropping systems.

\begin{tabular}{llll}
\hline Crop & Variety & Sowing time & Harvesting time \\
\hline T. Aman & BRRI dhan33 & 22 July & 22 October \\
Boro & BRRI dhan29 & 12 January & 29 April \\
Wheat & Gourav & 22 November & 20 March \\
Potato & Cardinal & 26 November & 3 March \\
Mungbean & BARI Mug 6 & 7, 23 March & 30 April and 1, 18, 25 \\
& & & May \\
\hline
\end{tabular}

The grouping always starts with a rainy day and rainfall for consecutive 5-day periods was added. The potential evapotranspiration and seepage and percolation rates for the same three days were taken together and used to compute effective rainfall using the equation:

$\mathrm{ERF}=\frac{E T+S \& P}{R F} \times 100$
Where ERF is the effective rainfall in percent with a maximum value of 100; $R F$ is the total amount of rainfall; ET is the potential evapotranspiration and $S \& P$ is the seepage and percolation losses of water for the 5-day period. Figure 1 presents monthly rainfall during the study period. 


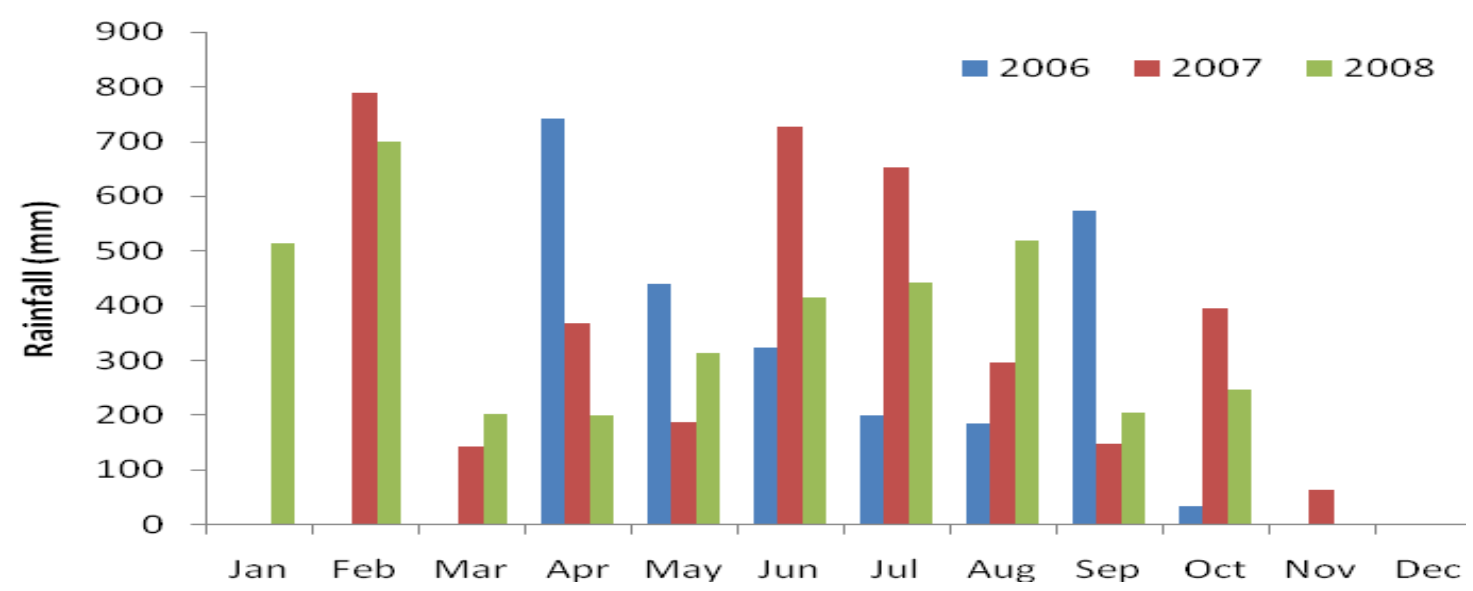

Fig. 1. Monthly rainfall (mm) during 2006-08.

Equivalent yield was calculated by the following equation:

$$
\text { EYrice } \frac{\text { Price of crop }(\mathrm{Tk} / \mathrm{t}) \times \text { Yield }(\mathrm{t} / \mathrm{ha})}{\text { Price of rice }(\mathrm{Tk} . / \mathrm{t})}
$$

Water productivity (WP) was computed by the following equation:

$$
\mathrm{WP}=\frac{\text { Yield }\left(\frac{\mathrm{kg}}{\mathrm{ha}}\right)}{\text { water applied }(\mathrm{mm})}
$$

\section{RESULTS AND DISCUSSION}

Cropping sequence. Rice equivalent yield (REY) varied significantly $(\mathrm{P}<0.05)$ among the three cropping sequences in 2006-07, 2007-08 and 200708 (Fig. 2). The maximum REY of 29.43, 20.95 and $26.34 \mathrm{t} \mathrm{ha}^{-1}$ was recorded in T. Aman-PotatoMungbean sequence in 2006-07, 2007-08 and 200708 respectively. Average over the year, the REY of $\mathrm{T}$. Aman-Potato-Mungbean cropping sequence was $56.4 \%$ higher than T. Aman-WheatMungbean and $63.3 \%$ higher than T. Aman-BoroFallow sequence. Inclusion of potato after $\mathrm{T}$. Aman rice instead of Boro rice increased the total productivity of the system. The minimum REY of $8.69,9.97$ and $9.47 \mathrm{t} \mathrm{ha}^{-1}$ was recorded in T. AmanBoro-Fallow sequence in the year 2006-07, 2007-08 and 2007-08 respectively. Sharma and Sharma
(2005) also reported higher productivity in $\mathrm{T}$. Aman-Potato-Mungbean cropping system.

Irrigation regimes. Rice equivalent yield productivity of different cropping sequences varied significantly $(\mathrm{P}<0.05)$ by irrigation regimes in 2006-07, but in 2007-08 and 2008-09, the variation was not significant (Fig. 3). In 2006-07, the highest rice equivalent yield $\left(18.3 \mathrm{t} \mathrm{ha}^{-1}\right)$ was recorded in $\mathrm{T}_{3}$ irrigation regimes arranged for different crops of the different cropping sequences. The lowest (15.04 $\left.\mathrm{t} \mathrm{ha}^{-1}\right)$ REY was recorded in $T_{1}$ irrigation regimes. Due to heavy rainfall in February, June and July, irrigation treatment was affected (Fig. 1).

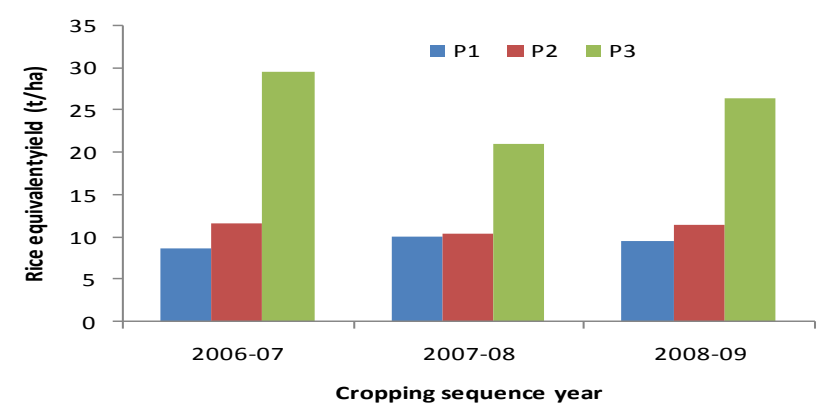

Fig. 2. Rice equivalent yield under different cropping sequences. 


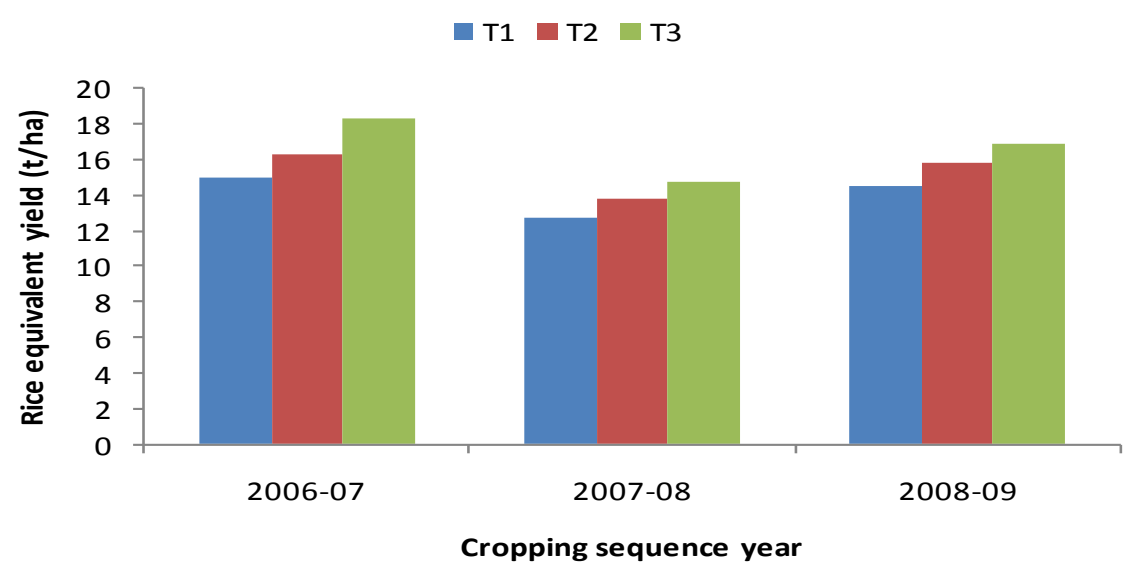

Fig. 3. Rice equivalent yield of different irrigation regimes of different cropping sequences.

Interaction of cropping sequence and irrigation regimes. Table 3 presents the yields of different crops and their equivalence to rice yield under different crop sequences with different levels of irrigation. Rice equivalent yield was significantly $(\mathrm{P}<0.05)$ different by different cropping sequences with different irrigation regimes in all the three years. Among the treatment combination, $\mathrm{T}$. Aman-Potato-Mungbean with $\mathrm{T}_{3}$ irrigation regimes assigned for the respective crops gave significantly higher rice equivalent yield of 33.40, 22.59 and 28.44 t ha $^{-1}$ in 2006-07, 2007-08 and 200809 respectively. It might be due to the cumulative effect of all the component crops yields those yielded maximum. The maximum T. Aman rice yield of 4.07, 3.35 and $3.87 \mathrm{t} \mathrm{ha}^{-1}$ was recorded under one irrigation at vegetative and two irrigations at reproductive stage $\left(T_{3}\right)$ in 2006-07, 2007-08 and 2008-09 respectively. The maximum potato yield of $14.33,28.78$ and 25.59 was recorded under three irrigations each at 20, 40 and 60 days after sowing $\left(T_{3}\right)$ in 2006-07, 2007-08 and 2008-09 respectively. The maximum mungbean yield of $1.01,1.17$ and $1.17 \mathrm{t} \mathrm{ha}^{-1}$ was recorded under two irrigations $\left(\mathrm{T}_{3}\right)$ in 2006-07, 2007-08 and 2008-09 respectively. The variations in yield equivalence were mostly governed by Rabi crops. The highest yield equivalence was in T. Aman-Potato-Mungbean cropping system, due to much higher yield of potato than wheat. Potato was also reported as a suitable Rabi crop in rice based cropping sequence (BRRI, 2006). Paul et al. (2013) also reported maximum productivity in Rice-Potato-Mungbean cropping system.

Irrigation water used and water productivity. Table 4 shows irrigation water used and water productivity of different cropping systems. Total water used and water productivity were significantly influenced by cropping systems and irrigation treatments in all the three years. The maximum total water of 1714, 1694 and $1786 \mathrm{~mm}$ was consumed by T. Aman-Boro-Fellow cropping sequence under $T_{1}$ irrigation regimes assigned for the respective crops in the cropping year 2006-07, 2007-08 and 2008-09 respectively. The higher amount of total consumed water was mostly governed by the Boro rice production under continuous standing water. In Rabi season, among the three crops cultivated in different cropping sequences, Boro rice used higher amount of total water than wheat and potato. The cropping sequence T. Aman-Wheat-Mungbean and T. Aman-Potato-Mungbean used almost similar amount of total water during the three growing seasons.

Water productivity was significantly influenced by cropping systems and irrigation regimes in all the three years. Among the cropping sequences, the maximum water productivity of $22.77,18.32$ and $23.05 \mathrm{~kg} \mathrm{ha}^{-1} \mathrm{~mm}$ was recorded in T. AmanPotato-Mungbean crop sequence in 2006-07, 200708 and 2008-09 respectively. Water productivity of T. Aman-Potato-Mungbean crop sequence under three irrigation regimes were not significantly differed in all the three years. However, the maximum water productivity of 23.41, 18.57 and $23.62 \mathrm{~kg} \mathrm{ha}^{-1} \mathrm{~mm}$ was recorded in $\mathrm{T}_{1}$ irrigation regimes assigned for $\mathrm{T}$. Aman, potato and mungbean crops in 2006-07, 2007-08 and 2008-09 respectively. The higher yield of potato raised the water productivity in T. Aman-PotatoMungbean cropping sequence. 
Table 3. Aman rice equivalent yield $\left(\mathrm{t} \mathrm{ha}^{-1}\right)$ of different crops in various rice based cropping systems, during 2006-07, 2007-08 and 2008-09.

\begin{tabular}{|c|c|c|c|c|c|c|c|}
\hline \multirow{2}{*}{\multicolumn{2}{|c|}{$\begin{array}{l}\text { Crop sequence with } \\
\text { water treatment }\end{array}$}} & \multicolumn{3}{|c|}{ Yield of crops $\left(\mathrm{t} \mathrm{ha}^{-1}\right)$} & \multicolumn{3}{|c|}{ Aman rice equivalent yield $\left(\mathrm{t} \mathrm{ha}^{-1}\right)$} \\
\hline & & \multirow{2}{*}{$\begin{array}{c}\mathrm{T} . \\
\text { Aman } \\
\text { season }\end{array}$} & \multirow{2}{*}{$\begin{array}{l}\text { Rabi/Boro } \\
\text { season }\end{array}$} & \multirow{2}{*}{$\begin{array}{c}\begin{array}{c}\text { Aus } \\
\text { season }\end{array} \\
\text { 2006-07 }\end{array}$} & \multirow{2}{*}{$\begin{array}{c}\text { Rabi/ } \\
\text { Boro season }\end{array}$} & \multirow{2}{*}{$\begin{array}{c}\text { Aus } \\
\text { season }\end{array}$} & \multirow{2}{*}{$\begin{array}{l}\text { Total equivalent } \\
\text { yield (TEY) }\end{array}$} \\
\hline & & & & & & & \\
\hline T. Aman- & $\mathrm{T}_{1}$ & 3.19 & 5.28 & - & - & - & 8.47 \\
\hline \multirow[t]{2}{*}{ Boro-Fallow } & $\mathrm{T}_{2}$ & 3.52 & 5.07 & - & - & - & 8.59 \\
\hline & $\mathrm{T}_{3}$ & 3.64 & 5.39 & - & - & - & 9.03 \\
\hline T. Aman- & $\mathrm{T}_{1}$ & 3.64 & 2.77 & 0.60 & 4.99 & 2.10 & 10.73 \\
\hline Wheat- & $\mathrm{T}_{2}$ & 3.64 & 3.02 & 0.67 & 5.44 & 2.35 & 11.42 \\
\hline Mungbean & $\mathrm{T}_{3}$ & 3.75 & 3.52 & 0.69 & 6.34 & 2.42 & 12.50 \\
\hline T. Aman- & $\mathrm{T}_{1}$ & 3.95 & 10.50 & 0.88 & 18.90 & 3.08 & 25.93 \\
\hline Potato- & $\mathrm{T}_{2}$ & 4.07 & 11.93 & 0.98 & 21.47 & 3.43 & 28.97 \\
\hline Mungbean & $\mathrm{T}_{3}$ & 4.07 & 14.33 & 1.01 & 25.79 & 3.54 & 33.40 \\
\hline \multirow{2}{*}{\multicolumn{2}{|c|}{$\mathrm{LSD}_{0.05}$}} & & & & & & 2.42 \\
\hline & & & & $2007-0$ & & & \\
\hline T. Aman- & $\mathrm{T}_{1}$ & 3.26 & 6.53 & - & - & - & 9.79 \\
\hline \multirow[t]{2}{*}{ Boro-Fallow } & $\mathrm{T}_{2}$ & 3.33 & 6.34 & - & - & - & 9.67 \\
\hline & $\mathrm{T}_{3}$ & 3.82 & 6.62 & - & - & - & 10.44 \\
\hline T. Aman- & $\mathrm{T}_{1}$ & 3.24 & 2.89 & 0.55 & 4.82 & 1.53 & 9.59 \\
\hline Wheat- & $\mathrm{T}_{2}$ & 3.64 & 2.95 & 0.59 & 4.92 & 1.64 & 10.2 \\
\hline Mungbean & $\mathrm{T}_{3}$ & 3.77 & 3.47 & 0.65 & 5.78 & 1.81 & 11.36 \\
\hline T. Aman- & $\mathrm{T}_{1}$ & 3.05 & 23.30 & 1.03 & 12.94 & 2.86 & 18.85 \\
\hline Potato- & $\mathrm{T}_{2}$ & 3.21 & 27.96 & 0.96 & 15.53 & 2.67 & 21.41 \\
\hline Mungbean & $\mathrm{T}_{3}$ & 3.35 & 28.78 & 1.17 & 15.99 & 3.25 & 22.59 \\
\hline \multirow{2}{*}{\multicolumn{2}{|c|}{ LSD $_{0.05}$}} & & & & & & 2.8 \\
\hline & & & & $2008-0$ & & & \\
\hline T. Aman- & $\mathrm{T}_{1}$ & 3.58 & 5.78 & - & - & - & 9.36 \\
\hline \multirow[t]{2}{*}{ Boro-Fallow } & $\mathrm{T}_{2}$ & 3.77 & 5.66 & - & - & - & 9.43 \\
\hline & $\mathrm{T}_{3}$ & 3.85 & 5.98 & - & - & - & 9.63 \\
\hline T. Aman- & $\mathrm{T}_{1}$ & 3.61 & 2.85 & 0.71 & 4.75 & 1.97 & 10.33 \\
\hline Wheat- & $\mathrm{T}_{2}$ & 3.75 & 3.04 & 0.94 & 5.07 & 2.61 & 11.43 \\
\hline Mungbean & $\mathrm{T}_{3}$ & 3.97 & 3.28 & 1.21 & 5.47 & 3.36 & 12.80 \\
\hline T. Aman- & $\mathrm{T}_{1}$ & 3.59 & 20.79 & 1.10 & 17.32 & 3.06 & 23.97 \\
\hline Potato- & $\mathrm{T}_{2}$ & 3.68 & 23.25 & 1.29 & 19.37 & 3.58 & 26.63 \\
\hline Mungbean & $\mathrm{T}_{3}$ & 3.87 & 25.59 & 1.17 & 21.32 & 3.25 & 28.44 \\
\hline $\mathrm{LSD}_{0.05}$ & & & & & & & 3.2 \\
\hline
\end{tabular}

Price of crops $\mathrm{kg}^{-1}$ during 2006-07: rice $=\mathrm{Tk} 10$, wheat $=\mathrm{Tk} 18$, potato $=\mathrm{Tk} 18$, mungbean $=\mathrm{Tk} 35$. Price of crops $\mathrm{kg}^{-1}$ during 2007-08: rice $=\mathrm{Tk} 18$, wheat $=\mathrm{Tk} 30$, potato $=\mathrm{Tk} 10$, mungbean $=\mathrm{Tk} 50$. Price of crops $\mathrm{kg}^{-1} \mathrm{during}$ 2008-09: rice $=$ Tk 18, wheat $=$ Tk 30, potato $=T k 15$, mungbean $=T k 50$. 
Bangladesh Rice J. 19(1):41 - 48, 2015

Table 4. Total water used $(\mathrm{mm})$ and water productivity of different rice based cropping systems during 2006-07, 2007-08 and 2008-09 at BRRI farm, Gazipur.

\begin{tabular}{|c|c|c|c|c|c|c|c|}
\hline \multicolumn{2}{|c|}{$\begin{array}{l}\text { Crop sequence with } \\
\text { water treatment }\end{array}$} & \multicolumn{3}{|c|}{$\begin{array}{l}\text { Total water use }(\mathrm{mm}) \\
\text { (inclusive rainfall, } \mathrm{mm} \text { ) }\end{array}$} & \multicolumn{3}{|c|}{$\begin{array}{l}\text { Water productivity } \\
\left(\mathrm{kg} \mathrm{ha}^{-1} \mathrm{~mm}\right)\end{array}$} \\
\hline & & 2006-07 & $2007-08$ & 2008-09 & $2006-07$ & $2007-08$ & 2008-09 \\
\hline T. Aman- & $\mathrm{T}_{1}$ & 1714 & 1694.0 & 1786 & 4.95 & 5.78 & 5.53 \\
\hline Boro- & $\mathrm{T}_{2}$ & 1374 & 1484.0 & 1386 & 6.26 & 6.52 & 6.35 \\
\hline Fallow & $\mathrm{T}_{3}$ & 1604 & 1559.0 & 1616 & 5.65 & 6.70 & 6.31 \\
\hline T. Aman- & $\mathrm{T}_{1}$ & 1099 & 1113.0 & 1061 & 9.77 & 8.62 & 9.28 \\
\hline Wheat- & $\mathrm{T}_{2}$ & 1315 & 1263.0 & 1143 & 8.68 & 8.08 & 9.05 \\
\hline Mungbean & $\mathrm{T}_{3}$ & 1445 & 1317.0 & 1196 & 8.66 & 8.63 & 9.72 \\
\hline T. Aman- & $\mathrm{T}_{1}$ & 1109 & 1015.0 & 1091 & 23.41 & 18.57 & 23.62 \\
\hline Potato - & $\mathrm{T}_{2}$ & 1311 & 1199.0 & 1066 & 22.15 & 17.86 & 22.21 \\
\hline Mungbean & $\mathrm{T}_{3}$ & 1483 & 1219.0 & 1213 & 22.75 & 18.53 & 23.33 \\
\hline $\mathrm{LSD}_{0.05}$ & & 130.4 & 110.6 & 93.7 & 3.2 & 2.5 & 3.8 \\
\hline $\mathrm{CV} \%$ & & 12.5 & 13.4 & 14.2 & 10.6 & 11.2 & 10.8 \\
\hline
\end{tabular}

Table 5. Benefit-cost ratio (BCR) of different rice based cropping systems during 2006-07, 2007-08 and 2008-09 at BRRI farm, Gazipur.

\begin{tabular}{|c|c|c|c|c|c|}
\hline \multicolumn{2}{|c|}{$\begin{array}{l}\text { Crop sequence with } \\
\text { water treatment }\end{array}$} & \multirow[t]{2}{*}{ Return per year (Tk ha-1) } & $\begin{array}{c}\text { Cost of } \\
\text { cultivation }\end{array}$ & \multirow[t]{2}{*}{ Net return (Tk) } & \multirow[t]{2}{*}{ BCR } \\
\hline \multicolumn{3}{|c|}{ 2006-07 } & & & \\
\hline T. Aman-Boro- & $\mathrm{T}_{1}$ & 84667 & 42672 & 41995 & 0.98 \\
\hline \multirow[t]{2}{*}{ Fallow } & $\mathrm{T}_{2}$ & 85867 & 40272 & 45595 & 1.13 \\
\hline & $\mathrm{T}_{3}$ & 90267 & 41314 & 48953 & 1.19 \\
\hline T. Aman- & $\mathrm{T}_{1}$ & 107260 & 46952 & 60308 & 1.30 \\
\hline Wheat- & $\mathrm{T}_{2}$ & 114210 & 48652 & 65558 & 1.35 \\
\hline Mungbean & $\mathrm{T}_{3}$ & 125010 & 49652 & 75358 & 1.53 \\
\hline T. Aman- & $\mathrm{T}_{1}$ & 259300 & 102084 & 157216 & 1.54 \\
\hline Potato - & $\mathrm{T}_{2}$ & 289740 & 103984 & 185756 & 1.79 \\
\hline Mungbean & $\mathrm{T}_{3}$ & 333990 & 105934 & 228056 & 2.15 \\
\hline \multicolumn{6}{|c|}{$2007-08$} \\
\hline \multirow{3}{*}{$\begin{array}{l}\text { T. Aman- Boro- } \\
\text { Fallow }\end{array}$} & $\mathrm{T}_{1}$ & 176220 & 50532 & 125688 & 2.49 \\
\hline & $\mathrm{T}_{2}$ & 174060 & 48944 & 125116 & 2.56 \\
\hline & $\mathrm{T}_{3}$ & 187920 & 52414 & 135506 & 2.59 \\
\hline \multirow{3}{*}{$\begin{array}{l}\text { T. Aman- } \\
\text { Wheat- } \\
\text { Mungbean }\end{array}$} & $\mathrm{T}_{1}$ & 172620 & 56196 & 116424 & 2.07 \\
\hline & $\mathrm{T}_{2}$ & 183600 & 60642 & 122958 & 2.03 \\
\hline & $\mathrm{T}_{3}$ & 204480 & 62124 & 142356 & 2.29 \\
\hline \multirow{3}{*}{$\begin{array}{l}\text { T. Aman- } \\
\text { Potato- } \\
\text { Mungbean }\end{array}$} & $\mathrm{T}_{1}$ & 339300 & 124827 & 214473 & 1.72 \\
\hline & $\mathrm{T}_{2}$ & 385380 & 128791 & 256589 & 1.99 \\
\hline & $\mathrm{T}_{3}$ & 406620 & 131231 & 275389 & 2.10 \\
\hline \multicolumn{6}{|c|}{ 2008-09 } \\
\hline \multirow{3}{*}{$\begin{array}{l}\text { T. Aman- Boro- } \\
\text { Fallow }\end{array}$} & $\mathrm{T}_{1}$ & 168480 & 57600 & 110880 & 1.93 \\
\hline & $\mathrm{T}_{2}$ & 169740 & 55484 & 114256 & 2.06 \\
\hline & $\mathrm{T}_{3}$ & 176940 & 55484 & 121456 & 2.19 \\
\hline T. Aman- & $\mathrm{T}_{1}$ & 185940 & 72257 & 113683 & 1.57 \\
\hline Wheat- & $\mathrm{T}_{2}$ & 205740 & 74007 & 131733 & 1.78 \\
\hline Mungbean & $\mathrm{T}_{3}$ & 230400 & 75757 & 154643 & 2.04 \\
\hline T. Aman- & $\mathrm{T}_{1}$ & 431460 & 102084 & 329376 & 3.23 \\
\hline Potato- & $\mathrm{T}_{2}$ & 479340 & 103984 & 375356 & 3.61 \\
\hline Mungbean & $\mathrm{T}_{3}$ & 511920 & 105934 & 405986 & 3.83 \\
\hline
\end{tabular}


Economics of different cropping systems/crop sequences. A wide variation in net return was observed among the crop sequences (Table 5). The maximum net return of Tk 2,28,056, 2,75,389 and 4,05,986 was recorded in T. Aman-PotatoMungbean crop sequence under $\mathrm{T}_{3}$ irrigation regimes of the respective crops during 2006-07, 2007-08 and 2008-09 respectively. It was followed by $\mathrm{T}_{2}$ irrigation regimes of the same crop sequence. Maximum net return in T. AmanPotato-Mungbean crop sequence was also reported by Paul et al. (2013). The maximum benefit cost ratio of 2.15 and 3.83 was recorded from T. Aman-Potato-Mungbean crop sequence under $\mathrm{T}_{3}$ irrigation regimes of the respective crops in 2006-07 and 2008-9 respectively. In 2007-08, the maximum benefit cost ratio of 2.59 was recorded in T. Aman-Boro-Fallow crop sequence under $\mathrm{T}_{3}$ irrigation regimes due to lower cost of cultivation.

\section{CONCLUSIONS}

The cropping sequence T. Aman-PotatoMungbean with $\mathrm{T}_{3}$ irrigation regimes assigned for the respective crops gave the highest rice equivalent yield. The variation in yield equivalence was mostly governed by potato. The highest water productivity was obtained from $\mathrm{T}$. Aman-Potato-Mungbean with $\mathrm{T}_{1}$ irrigation regimes. Maximum net return and maximum BCR values from T. Aman-Potato-Mungbean cropping sequence with $\mathrm{T}_{3}$ irrigation regimes indicated that the combination would be suitable for getting higher yield and economic return.

\section{REFERENCES}

BBS (Bangladesh Bureau of Statistics). 2009. Ministry of Planning. Government of the peoples republic of Bangladesh. Dhaka, Bangladesh. Pp. 120-128.

Bhuiyan, N I, D N R Paul and M A Jabbar. 2004. Feeding the extra millions by 2025: challenges for rice research and extension in Bangladesh. In: $\mathrm{M} \mathrm{M}$ Haque, $\mathrm{A} \mathrm{R}$ Gomosta and M R Mondal. Proc. of the workshop on modern rice cultivation in Bangladesh Rice Research Institute, Gazipur 1701. Pp 1-24.
Bhuiyan, S I, M A Sattar, M A K Khan. 1995. Improving water use efficiency in rice through wet seeding. Irrigation Sci. 16: 1-8.

BRRI. 2006. Bangladesh Rice Research Institute Annual Report, 2005-6.

Dawe, D, S Frolking and C Li. 2004. Trends in rice wheat area in China. Field Crops Res. 87: 89-95

FRG (Fertilizer Recommendation Guide). 1997. Bangladesh Agricultural Research Council. Farmgate, Dhaka. P. 196.

Guerra, L C, S I Bhuiyan, T P Tuong, R Barker. 1998: Producing more rice with less water from irrigated systems. SWIM Paper 5. IWM/IRRI, Colombo, Sri Lanka, 24pp.

Haque, M S. 1998. Integrated nutrient management with inorganic and biofertilizers in legume based cropping patterns. Proc. of the national workshop on integrated nutrient management for crop production and soil fertility. 24-25 march, 1998. Bangladesh Agricultural Research Council. Farmgate, Dhaka. P.99-109.

Ladha, J K, H Pathak, A T Padre, D Dawe and R K Gupta. 2003. Productivity trends in intensive rice-wheat cropping systems in Asia. In: J K Ladha, J E Hill, J M Duxbury, R K Gupta and R J Buresh (eds). Improving the productivity and sustainability of Rice-Wheat Systems: Issues and Impacts. ASA Special Pub. 65: 45-76.

Paul, P L C, M N Hasan, M A Rashid, M Paul and S Paul. 2013. Water productivity evaluation for rice based cropping system in Gazipur district of Bangladesh. Ecofriendly Agril J. 6(2): 279-284.

Rahman, M W, R Ahmed. 2008. 'Shallow tube well irrigation business in Bangladesh,' Paper presented at Summary and Synthesis Workshop at Kathmundu, Nepal, March 20-24, 2008.

Sharma, S K and S N Sharma. 2005. Effect of crop diversification of rice-wheat cropping system on productivity and profitability. J. Sus. Agric. 26(1): 39-48. 